\title{
Macrobenthic community response to the Marenzelleria viridis (Polychaeta) invasion of a Danish estuary
}

\author{
Matthieu Delefosse ${ }^{1, *}$, Gary T. Banta ${ }^{2}$, Paula Canal-Vergés ${ }^{1,3}$, Gil Penha-Lopes ${ }^{1,4}$, \\ Cintia O. Quintana ${ }^{1}$, Thomas Valdemarsen ${ }^{1}$, Erik Kristensen ${ }^{1}$ \\ ${ }^{1}$ Institute of Biology, University of Southern Denmark, Campusvej 55, 5230 Odense M, Denmark \\ ${ }^{2}$ Department of Environmental, Social and Spatial Change, Roskilde University, Universitetsvej 1, 4000 Roskilde C, Denmark \\ ${ }^{3}$ DHI Water Environment Health, Agern Allé 5, 2970 Hørsholm, Denmark \\ ${ }^{4}$ Laboratório Marítimo da Guia, Centro de Oceanografia, Faculdade de Ciências da Universidade de Lisboa, \\ Avenida Na Senhora do Cabo, 939, 2750-374 Cascais, Portugal
}

\begin{abstract}
We investigated the invasion of the non-native polychaete Marenzelleria viridis in a shallow Danish estuary, Odense Fjord. Three datasets with different spatial and temporal resolution were examined to describe the invasion of $M$. viridis and to investigate its effect on the native benthic community with focus on the 2 common polychaetes, Nereis (Hediste) diversicolor and Arenicola marina. Marenzelleria viridis colonized Odense Fjord rapidly, and within $3 \mathrm{yr}$ it had spread to $\sim 50 \%$ of the estuary. The population development of $M$. viridis in Odense Fjord followed the 'boom-bust' pattern that is typical for many invaders. $M$. viridis is now firmly established and has reached an overall abundance of 100 to 200 individuals (ind.) $\mathrm{m}^{-2}$ with local maxima of up to 1200 ind. $\mathrm{m}^{-2}$. Its distribution is apparently regulated by abiotic parameters that prevent its establishment in the oligohaline and more silty parts of Odense Fjord. There was a positive interaction between $M$. viridis and the native $A$. marina. Otherwise the introduction of $M$. viridis was synchronous with a decrease of several macroinvertebrates species, especially $N$. diversicolor. The latter is still the dominant species in Odense Fjord, but its density has decreased by $>60 \%$ in areas colonised by $M$. viridis. We do not expect that $N$. diversicolor disappears completely in this estuary, but it will probably be displaced to refuge areas where $M$. viridis cannot survive. Decrease in the population size of a key native species such as $N$. diversicolor might have significant ecological implications at the ecosystem level with respect to biodiversity and nutrient cycling.
\end{abstract}

KEY WORDS: Invasive species · Marenzelleria viridis $\cdot$ Nereis (Hediste) diversicolor $\cdot$ Arenicola marina $\cdot$ Benthic communities $\cdot$ Biological interactions $\cdot$ Polychaetes $\cdot$ Regime shift

\section{INTRODUCTION}

Central questions in studies of biological invasions are how and to which extent non-native species affect the recipient ecosystem (Reise et al. 2006). These questions have been increasingly relevant in the marine environment for 2 major reasons. (1) The number of non-native species is rising as a result of increasing ship transportation (ballast water and hull fouling), aquaculture and man-made waterways (Leppäkoski \& Olenin 2000, Gollasch 2006). (2) Nonnative species constitute a possible cause for alteration of ecosystem processes and displacement of native species (Reise et al. 2006). Estuaries along the European coastal zone are 'hot spots' for introduction of non-native species (Zaiko et al. 2011). These areas 
have often low species diversity and potentially empty niches resulting from their unpredictable environmental conditions (salinity, temperature and oxygen) concurrent with intense anthropogenic disturbances (Reise et al. 2006, Zaiko et al. 2011). It appears that benthic communities are particularly prone to colonization by non-native species since $>50 \%$ of the 1000 species registered as non-native in European coastal waters are benthic macroinvertebrates (Gollasch 2006). These biological invasions may have implications for the ecological functioning of estuaries because benthic macroinvertebrates are components of the estuarine food web and important controllers of biological, chemical and physical processes in these environments (Kristensen et al. 2012).

Introduced polychaete species of the Marenzelleria genus are widespread in the Baltic Sea and Kattegat areas (Leppäkoski \& Olenin 2000, Zaiko et al. 2011). To date 3 siblings have been identified here: $M$. arctia seems restricted to the most northern part, $M$. neglecta to the central and most southern part of the Baltic Sea, whereas only $M$. viridis is found at higher salinity in Danish waters at the mouth of the Baltic Sea (Blank et al. 2008, Christoffersen 2010). In some regions, the invasion of these species is associated with a negative effect because they rapidly became dominant and dramatically changed the benthic fauna communities (Zmudzinski 1996, Cederwall et al. 1999, Essink 1999, Zaiko et al. 2011). For example, Marenzelleria spp. invasion has been linked to low survival of the polychaete Nereis (Hediste) diversicolor (Essink \& Kleef 1993, Kotta et al. 2001) and is therefore of special concern in areas where the latter is common. Conversely, Marenzelleria spp. invasion had only limited effects on the native benthic fauna in certain parts of the Dutch Wadden Sea and the Baltic Sea where it appears to constitute just an additional species (Essink \& Dekker 2002). Thus, interactions of Marenzelleria spp. with other benthic species appear to vary greatly between regions and are likely related to the sensitivity of the native community and the environmental specificity of the habitat as well as the abundance and invasion stage (Reise et al. 2006, Zaiko et al. 2011).

Monitoring programmes in Denmark first confirmed the introduction of Marenzelleria viridis along the Danish west coast in the 1990's (Essink 1999, Thomsen et al. 2009). It subsequently became a successful invader in other Danish coastal areas and estuaries as its presence has now been confirmed throughout most Danish coasts in the Kattegat and Belt areas (Fig. 1). This is probably the result of a biological capacity of this species to establish success-

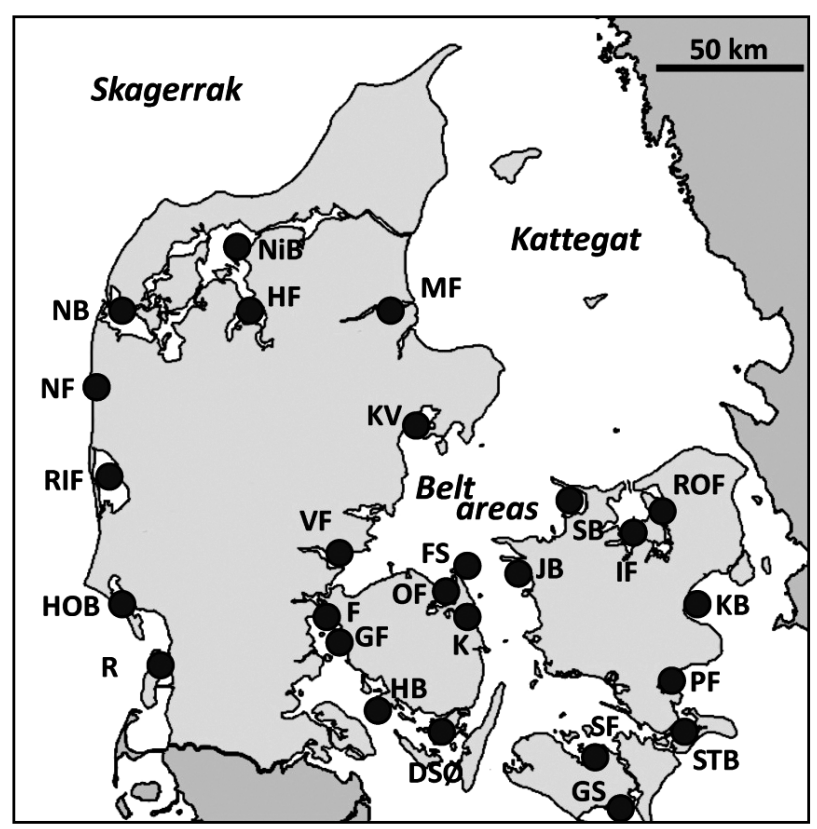

Fig. 1. Marenzelleria viridis. Occurrences of the non-native polychaete $M$. viridis recorded around Denmark between 2005 and 2010. Locations: Det Synfynske Øhav (DSØ), Fænøsund (F), Fynshoved (FS), Gamborg Fjord (GF), Guldborg Sund (GS), Helnæs Bugt (HB), Hjarbæk Fjord (HF), Ho Bugt (HOB), Isefjorden (IF), Jammerland Bugt (JB), Kalø Vig (KV) Kertinge Nor (K), Køge Bugt (KB), Mariager Fjord (MF), Nibe Bugt (NiB), Nissum Bredning (NB), Nissum Fjord $(\mathrm{NF})$, Odense Fjord (OF), Præstø Fjord (PF), Ringkøbing Fjord (RIF), Roskilde Fjord (ROF), Rømø (R), Sakskøbing Fjord (SF), Sejerøbugten (SB), Stege Bugt (STB), Vejle Fjord (VF). Data were compiled from the Ministry of Environment database, Christoffersen (2010), Zaiko et al. (2011) and authors' unpubl. data

fully in new areas (Ricciardi \& Rasmussen 1998). Species of the genus Marenzelleria have the required tolerance (Hahlbeck et al. 2000, Blank et al. 2004) to withstand salinity fluctuations and exposure to anoxia or even sulfidic events that are common in Danish estuaries (Conley et al. 2000). Furthermore, it has a high reproductive capacity (Essink \& Kleef 1993) that enables it to spread rapidly and over long distances (>100 $\mathrm{km} \mathrm{yr}^{-1}$; Leppäkoski \& Olenin 2000).

This study aims at establishing how the invasion of the polychaete Marenzelleria viridis affects the native benthic fauna in Danish estuaries. (1) We describe the past and current spatial population dynamics of $M$. viridis in the shallow Danish estuary, Odense Fjord. (2) We evaluate the implications of $M$. viridis for the native benthic fauna community. We focus on interactions between $M$. viridis and the 2 ecologically important native polychaete species in Danish estuaries, Nereis diversicolor and Arenicola marina. 


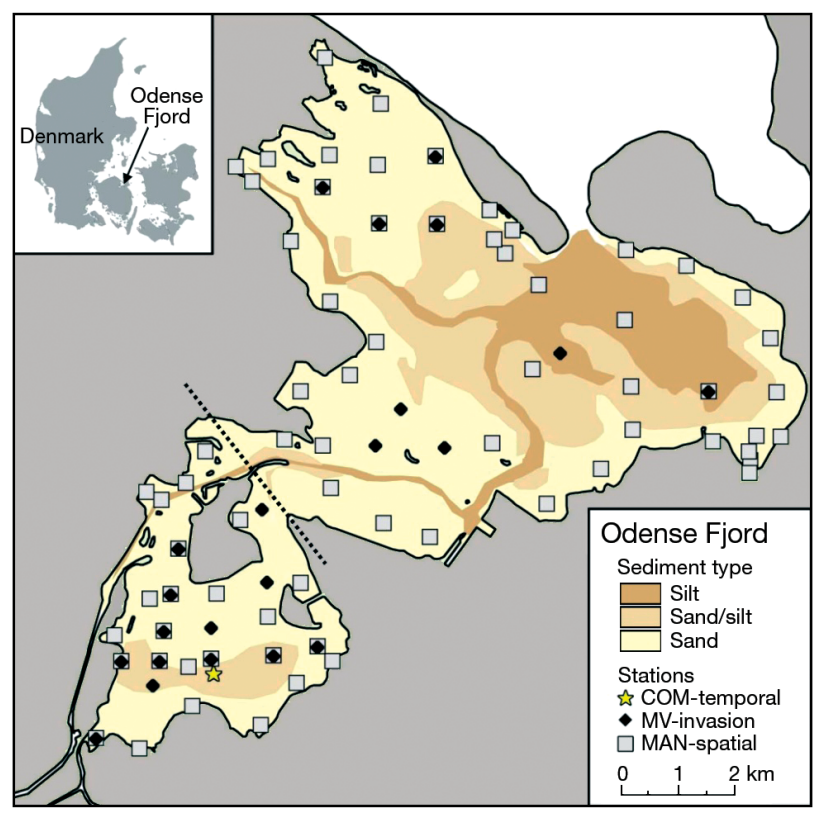

Fig. 2. Odense Fjord with sediment type and sampling locations of the 3 surveys: COM-temporal, MV-invasion and MAN-spatial (see 'Quantification of $M[$.$] viridis invasion$ and its effect on the native fauna' for detailed explanations). Dashed line: separation between inner and outer part of the estuary

\section{MATERIALS AND METHODS}

\section{Study site}

Odense Fjord is a shallow microtidal estuary (sensu Conley et al. 2000) separated into 2 basins (Fig. 2). The inner basin covers $\sim 11 \mathrm{~km}^{2}$ with mean depth of $\sim 1 \mathrm{~m}$, whereas the larger $\left(\sim 50 \mathrm{~km}^{2}\right)$ outer basin has an average depth of $\sim 3 \mathrm{~m}$. The main freshwater input to the estuary is the Odense River located at the head of the inner basin whereas seawater is exchanged through a narrow opening at the mouth of the estuary (Fig. 2; Riisgård et al. 2008). Consequently, the average salinity in the outer basin is higher $(\sim 20)$ than in the inner basin (10 to 15$)$. The salinity in the inner basin is controlled by freshwater discharge from the Odense River and by a salt wedge through the deep (>6 m) shipping channel that runs throughout the estuary. Thus, the salinity in the inner part of the estuary occasionally drops $<5$ during winter and spring when run-off from land is most intense. Sediments in the shallow areas mainly consist of low organic $(<3 \%)$ fine sand, but the deeper areas trap fine particles and form organicrich $(>10 \%)$ silty sediments (Fig. 2; Riisgård et al. 2008). As many other Danish estuaries, Odense Fjord is characterised by a widespread and high abundance of the polychaete Nereis diversicolor and local but dense population of Arenicola marina (Riisgård \& Banta 1998, Conley et al. 2000, Riisgård et al. 2004). Recent surveys, based on $>25$ stations, have shown that the benthic fauna in Odense Fjord is characterised by large abundances of the oligochaete Tubificoides benedii (on average $25 \%$ ), crustacean Corophium volutator $(10 \%)$, gastropods from the Hydrobiidae family (20\%), and the polychaetes $N$. diversicolor (10\%) and Pygospio elegans (20\%). These species together constitute $\sim 85 \%$ of the total abundance (authors' unpubl.). The vegetation mainly consists of seagrasses (Zostera marina and Ruppia maritima) and macroalgae (Fucus vesiculosus and Ulva lactuca; Riisgård et al. 2008).

\section{Quantification of Marenzelleria viridis invasion and its effect on the native fauna}

In order to describe the temporal and spatial dynamics of Marenzelleria viridis invasion and its effect on the benthic community structure in Odense Fjord, 3 different datasets were utilized (Table 1): (1) MVinvasion from spatial observations of $M$. viridis and Nereis diversicolor over a 10 yr period (1998 to 2007); (2) COM-temporal is a $25 \mathrm{yr}$ long dataset (1983 to 2007) at 1 location of the benthic community associated with the introduction of M. viridis; (3) MANspatial is an extensive estuary-wide survey conducted in 2008 and 2010 to establish the current distribution and abundance of $M$. viridis, Arenicola marina and $N$. diversicolor. The MV-invasion and COM-temporal surveys were generated by the
Table 1. Summary of the 3 sampling designs used in this study. see 'Quantification of $M[$.$] viridis invasion and its effect on the native fauna' for detailed$ explanations

\begin{tabular}{|lcccc|}
\hline Species & Station(s) & Period & Sampling & Replicate \\
\hline $\begin{array}{l}\text { MV-invasion } \\
\text { Marenzelleria viridis }\end{array}$ & 23 & $1998-2007$ & 10 & 1 \\
$\quad \begin{array}{l}\text { Nereis diversicolor } \\
\text { COM-temporal }\end{array}$ & & & & 10 \\
$\quad \begin{array}{l}\text { Full community } \\
\text { MAN-spatial }\end{array}$ & 1 & $1983-2007$ & 37 & \\
$\quad \begin{array}{l}\text { Marenzelleria viridis } \\
\text { Arenicola marina }\end{array}$ & & & & 4 \\
$\quad$ Nereis diversicolor & 70 & 2008 and 2010 & $1-2$ & \\
\hline
\end{tabular}


County of Fyn as part of the National Monitoring Programme (Conley et al. 2002).

Marenzelleria viridis invasion (MV-invasion). The temporal change in the spatial distribution of $M$. viridis was monitored over an estuary-wide grid of 23 stations separated by $\sim 100 \mathrm{~m}$ (Fig. 2). Only 1 replicate sample was taken at each station either during spring or summer every year from 1998 to 2007 (Table 1). Sampling was conducted using a $30 \mathrm{~cm}$ long and $12.8 \mathrm{~cm}$ in diameter steel corer $\left(0.0129 \mathrm{~m}^{2}\right)$ to retrieve a representative portion of the sediment $(0$ to $25 \mathrm{~cm}$ depth). The sediment was sieved on the location through a $1 \mathrm{~mm}$ mesh, and retained material was immediately preserved in buffered $4 \%$ formaldehyde. In the laboratory, samples were washed clean of formaldehyde, and macrofauna was sorted after staining with Rose Bengal. Sorted macrofauna was then preserved in $70 \%$ ethanol before species identification and counting. Only results for $M$. viridis and Nereis diversicolor were considered in this study. Maps of the temporal and spatial dynamics of $M$. viridis invasion in Odense Fjord were generated with GIS software (MapInfo Professional 8.0).

Benthic community temporal response (COMtemporal). Temporal changes of the total benthic community were monitored at a $\sim 0.9 \mathrm{~m}$ deep station in the inner part of the estuary (Fig. $2 ; 55.4512^{\circ} \mathrm{N}$, $10.4617^{\circ} \mathrm{E}$ ). A total of 10 replicates were taken within a radius of $20 \mathrm{~m}$ during each spring and autumn almost every year from 1983 to 2007 (Table 1). This survey was carried out with the sampling technique described for the MV-invasion survey.

Multivariate analyses of raw abundance data were done using the software package Primer 6 (Clarke \& Gorley 2006). Prior to analyses, some of the taxonomically difficult groups were pooled to the lowest reliable taxonomic level (e.g. Corophium genus, Hydrobiidae family and Polydora genus). This operation has marginal consequences on the outcome of subsequent analysis (Somerfield \& Clarke 1995). To correct for the different levels of spatial aggregation of the species and downweigh the occurrence of erratic species, raw data were dispersion-weighted by dividing the abundance of each species by their respective index of dispersion, the variance to mean ratio, for each sampling date (Clarke et al. 2006a, Jørgensen et al. 2011). Subsequently, the data were square root transformed to retain the main community structure and lower the importance of abundant species (Clarke et al. 2006a). Changes in the community over time were determined by comparing the similarity of averages using the Bray-Curtis (BC) coefficient on which all subsequent multivariate tests were based (Clarke et al. 2006b). Relationships among assemblages were visualised using nonmetric multidimensional scaling (MDS) where the distance ranking between points on the diagram matches the BC similarity ranking between communities at different times (Clarke 1993). To test for changes in the community before (B) and after (A) the introduction of Marenzelleria viridis, the data were analysed using a 1-way analysis of similarity (ANOSIM). The procedure generates an R statistics that quantifies the degree of segregation between the groups and a p-value indicating the significance of the difference observed. R usually ranges between 0 and 1 , and takes the value 1 when all communities within groups are more similar than any community between groups (Clarke 1993). The SIMPER technique was also used to identify the extent by which the 2 periods differed and how species contributed to this difference (Clarke \& Gorley 2006). The most influential species were explored by the BVSTEP procedure by estimating the Spearman correlation of temporal variations for a chosen subset of species and the full fauna dataset. Furthermore, this procedure also identifies a subset of species having highly correlated temporal variations $\left(\rho_{\text {Spearman }}>\right.$ 0.95) with the entire community (Clarke \& Warwick 1998).

Spatial distribution and interactions among polychaete species (MAN-spatial). Two estuary-wide surveys were conducted to investigate the current spatial distribution of Marenzelleria viridis and 2 important native polychaete species in Odense Fjord, Arenicola marina and Nereis diversicolor (Riisgård \& Banta 1998, Riisgård et al. 2004). These surveys consisted of 24 and 50 stations sampled in spring 2008 and autumn 2010, respectively (Table 1, Fig. 2). At all stations the density of polychaetes was determined from 4 replicate samples. Raw data from the 2 surveys were merged and in case of station-overlap, the data from the 2 surveys were averaged to provide a grid of 70 stations in total (Table 1). Samples were collected using a slightly larger corer $\left(0.0177 \mathrm{~m}^{2}\right)$ than in the other surveys. Samples were preserved as described above, but only $M$. viridis, $A$. marina and $N$. diversicolor were quantified. Arenicola marina density in 2008 was based on the corer technique whereas in 2010 it was supplemented by counting faecal casts inside a $0.5 \times 0.5 \mathrm{~m}$ steel frame (Reise et al. 2001). For the large bodied lugworm, the latter method was assumed more representative than the corer technique. The frame technique may be inappropriate for detecting the smallest individuals $<1 \mathrm{~g}$ (Valde- 
marsen et al. 2011), but it provides better spatial resolution (max. resolution: $1 \mathrm{~m}^{2}$ ) compared to the core technique (max. resolution: $14 \mathrm{~m}^{2}$ ). A comparison between results obtained from both methods in 2010 showed a strong correlation between the methods for abundance $>10 \mathrm{~m}^{-2}(\mathrm{r}=0.9, \mathrm{p}<0.001)$ and that frame technique results represented $\sim 40 \%$ of the results obtained with the corer. Data collected in 2008 were therefore corrected by this factor.

Maps of the spatial distribution of Marenzelleria viridis, Nereis diversicolor and Arenicola marina were constructed using GIS software (MapInfo Professional 8.0). The distribution was based on the inverse distance weighting interpolation method (Mitas \& Mitasova 1999). Thus, the estuary was divided in $15 \times 15 \mathrm{~m}$ cells in which the polychaete density was estimated from the distance weighted average of the polychaete abundance at the 70 stations. Since none of the examined polychaete species were observed in the fluid mud (authors' unpubl. data), hypothetical stations with zero abundance were added along the shipping channel.

\section{RESULTS}

\section{Marenzelleria viridis invasion (MV-invasion)}

Marenzelleria viridis was observed for the first time at one station in the inner part of Odense
Fjord in 2002 and it spread hereafter rapidly to most of the surveyed area (Fig. 3). In 2003 and 2004 it was observed on 25 and $75 \%$ of the monitoring stations, respectively. Subsequently, $M$. viridis was present at 50 to $75 \%$ of the monitoring stations until the end of the survey in 2007 (Fig. 3). Marenzelleria viridis was never observed at 5 stations located in the most inner parts of the estuary with lowest salinity and the silty areas (Figs. 2 \& 3). Although the $M$. viridis abundance was site-specific, the temporal changes were similar at all stations. The rapid initial increase in abundance during the first $2 \mathrm{yr}$, reaching maximum values ranging from 150 to 3000 ind. $\mathrm{m}^{-2}$, was followed by a slow decrease from $\sim 20$ to $70 \%$ of this level at the end of the survey in 2007 (Fig. 4).

The pronounced decline in the overall abundance of Nereis diversicolor after 2001 corresponded with the introduction of Marenzelleria viridis in the estuary (Fig. 4). However, N. diversicolor remained throughout the survey period present at $75 \%$ of the examined 23 stations. The abundance of $N$. diversicolor at stations colonised by $M$. viridis on average dropped by $63 \%$ from an average of 1490 before 2002 to 550 ind. $\mathrm{m}^{-2}$ after (Fig. 4). In contrast, the average abundance of this species at stations that were not colonised by $M$. viridis was $>1000$ ind. $\mathrm{m}^{-2}$ throughout the survey period, except for 2002 and 2003 where the abundance reached 650 and 450 ind. $\mathrm{m}^{-2}$, respectively.
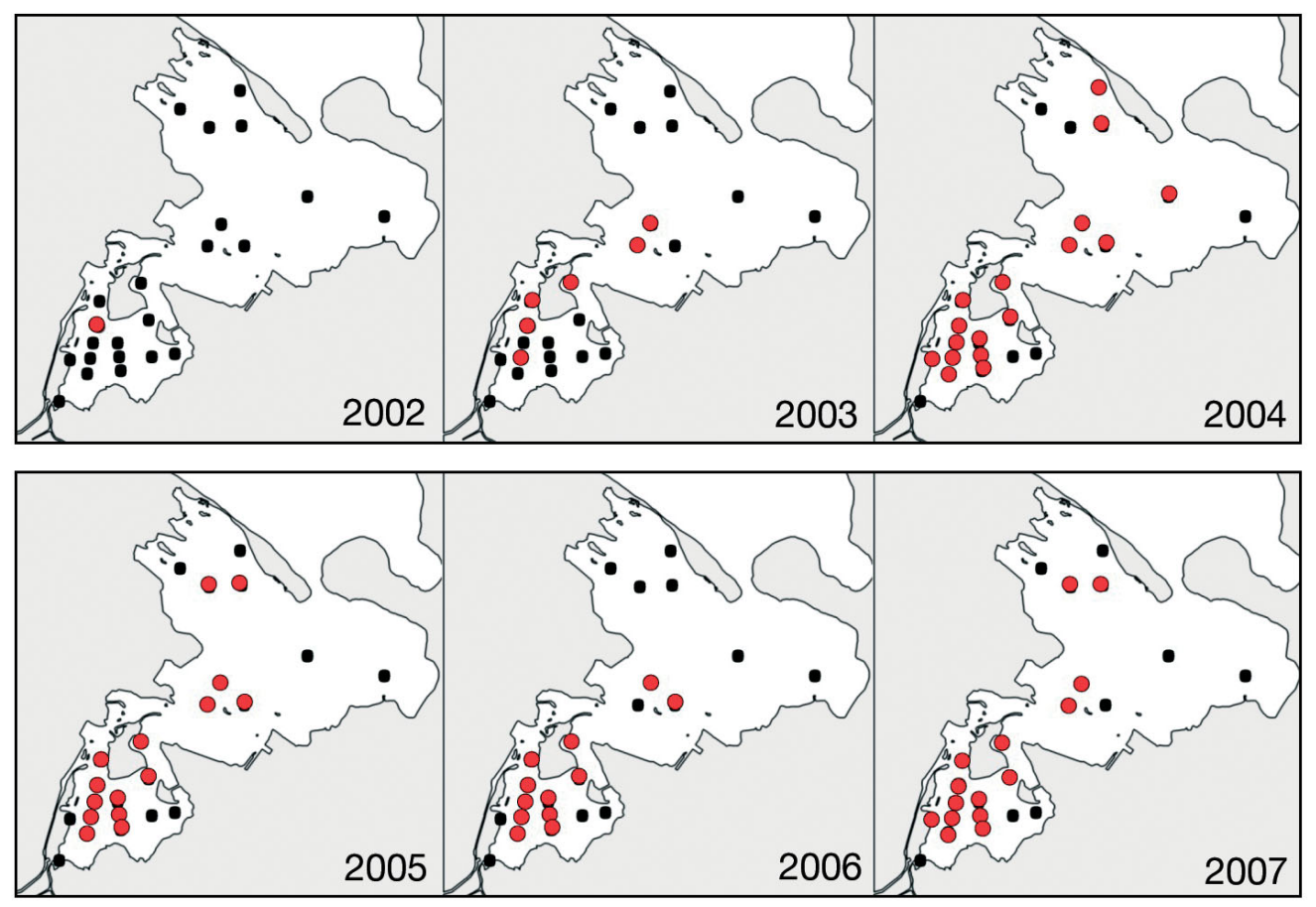

Fig. 3. Marenzelleria viridis. MV-invasion survey. Distribution and temporal change of non-native $M$. viridis in Odense Fjord from 2002 to 2007. Filled circles: presence (red) or absence (black) of $M$. viridis. $M$. viridis was not observed prior to 2002 


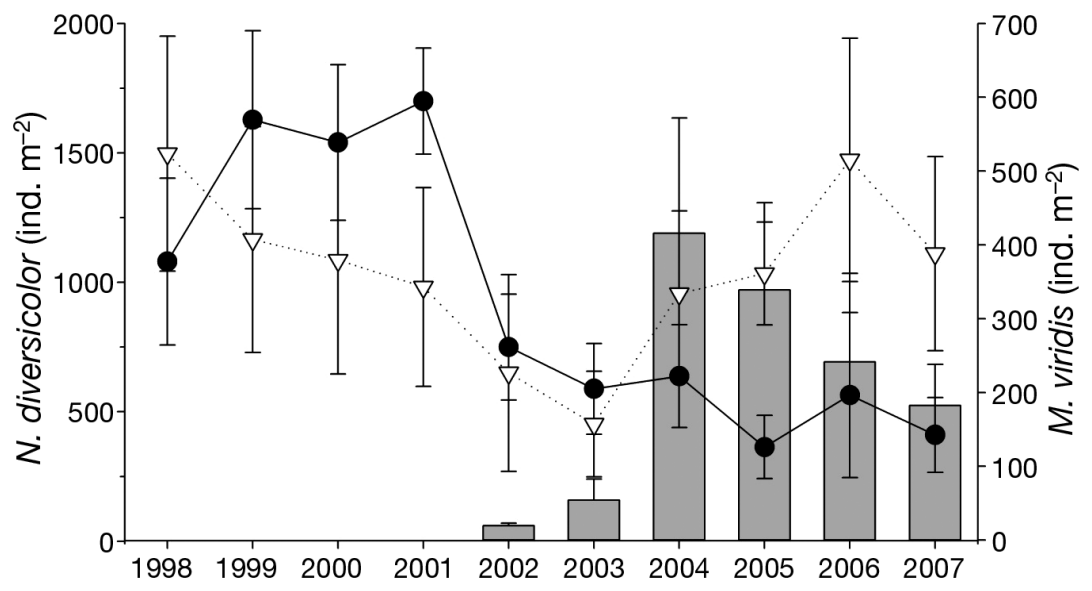

Fig. 4. Marenzelleria viridis and Nereis diversicolor. MV-invasion survey. Temporal change in $M$. viridis (grey columns) abundance in Odense Fjord represented by the average for the entire grid of 23 stations. Temporal change in density (means $\pm \mathrm{SE}$ ) of $N$. diversicolor at stations colonised $(\mathbf{O})$ and never colonised $(\nabla)$ by $M$. viridis

\section{Benthic community temporal response (COM-temporal)}

More than 55000 macroinvertebrate individuals belonging to 22 benthic taxa were identified over the $25 \mathrm{yr}$ of the COM-temporal survey, and half of the identified species were polychaetes (Table 2). Overall, $95 \%$ of the total abundance consisted of species from the 3 taxonomic groups. The class Gastropoda was represented by the Hydrobiidae family that contributed $76 \%$ to the total species abundance (mainly Hydrobia ulvae and Potamopyrgus antipodarum), the class Polychaeta contributed $16 \%$ (mainly Nereis diversicolor), and the class oligochaeta contributed 3\% (mainly Tubificoides benedii; Table 2).

Marenzelleria viridis was first recorded at the COM-temporal station in 2004 and its average abundance remained low (10 to $\left.70 \mathrm{~m}^{-2}\right)$. Nevertheless, there was a strong shift in the benthic community composition synchronous with its introduction. The MDS plot (Fig. 5a) shows that all dates before 2004 were clearly grouped together, indicating that temporal variations were minimal, although with some cyclic trends. A distinct change of the community was evident from 2003 to 2004 (ANOSIM, R $=0.93, \mathrm{p}<0.001$ ). Subsequently, the community continued
Table 2. COM-temporal survey. Macrofaunal composition (abundance $\mathrm{m}^{-2}$; means \pm SD) before and after the introduction of $M$. viridis in 2004 . Only the 16 species that accounted for $>5 \%$ of total counts are shown

\begin{tabular}{|llcc|}
\hline Class & Species & $1983-2003$ & $2004-2007$ \\
\hline Polychaeta & Arenicola marina & $0.6 \pm 2$ & $70 \pm 6$ \\
& Eteone longa & $2 \pm 6$ & $28 \pm 5$ \\
& Nereis diversicolor & $1400 \pm 500$ & $125 \pm 14$ \\
& Heteromastus filiformis & $12 \pm 10$ & $30 \pm 2$ \\
& Marenzelleria viridis & 0 & $33 \pm 4$ \\
& Polydora spp. & $64 \pm 131$ & $32 \pm 5$ \\
& Pygospio elegans & $5 \pm 14$ & $18 \pm 21$ \\
Bivalvia & Cerastoderma glaucum & $29 \pm 52$ & $23 \pm 6$ \\
& Mya arenaria & $23 \pm 31$ & $1.2 \pm 0.5$ \\
& Mytilus edulis & $2 \pm 5$ & 0 \\
Gastropoda & Hydrobiidae fam. & $7200 \pm 5300$ & $6400 \pm 600$ \\
& Littorina spp. & $490 \pm 640$ & $220 \pm 50$ \\
Insecta & Chironomidae indet. & $8 \pm 16$ & $44 \pm 10$ \\
Others & Corophium spp. & $125 \pm 200$ & $15 \pm 3$ \\
& Nemertini indet. & $18 \pm 33$ & $35 \pm 7$ \\
& Tubificoides benedii & $180 \pm 225$ & $175 \pm 20$ \\
\hline
\end{tabular}

to change as indicated by strong dissimilarities between consecutive dates until the end of the survey in 2007 (Fig. 5a). Overall, M. viridis introduction increased $(\mathrm{p}=0.007)$ the species richness (mean $\pm \mathrm{SD}$ ) from $9.5 \pm 2.0(\mathrm{n}=30)$ to $12 \pm 2.4$ $(\mathrm{n}=7)$. The SIMPER procedure identified that the community before and after 2004 was $60 \%$ dissimilar and the species contributing the most to this difference were Nereis diversicolor $(27 \%)$ and Arenicola marina $(10 \%)$. In fact, population changes of $N$. diversicolor alone were so influential that the BVSTEP procedure showed an almost perfect match between the temporal pattern of this species and that of the whole community $\left(\rho_{\text {Spearman }}=0.82\right.$, $\mathrm{p}<0.001$ ). While $N$. diversicolor was most abundant before 2004, its total density decreased $>10$-fold, from 1400 to 125 ind. $\mathrm{m}^{-2}$ after introduction of $M$. viridis and A. marina (Fig. 5b-d, Table 2). The negative interaction between $N$. diversicolor and $A$. marina was nearly significant $(\mathrm{r}=-0.65, \mathrm{p}=0.07)$, whereas the relation between $N$. diversicolor and $M$. viridis was not significant $(\mathrm{r}=-0.34, \mathrm{p}=0.41$, Fig. 6). The abundances of $M$. viridis and A. marina, on the other hand, were strongly positively correlated ( $r=0.83, p=0.01$; Fig. 6$)$. 

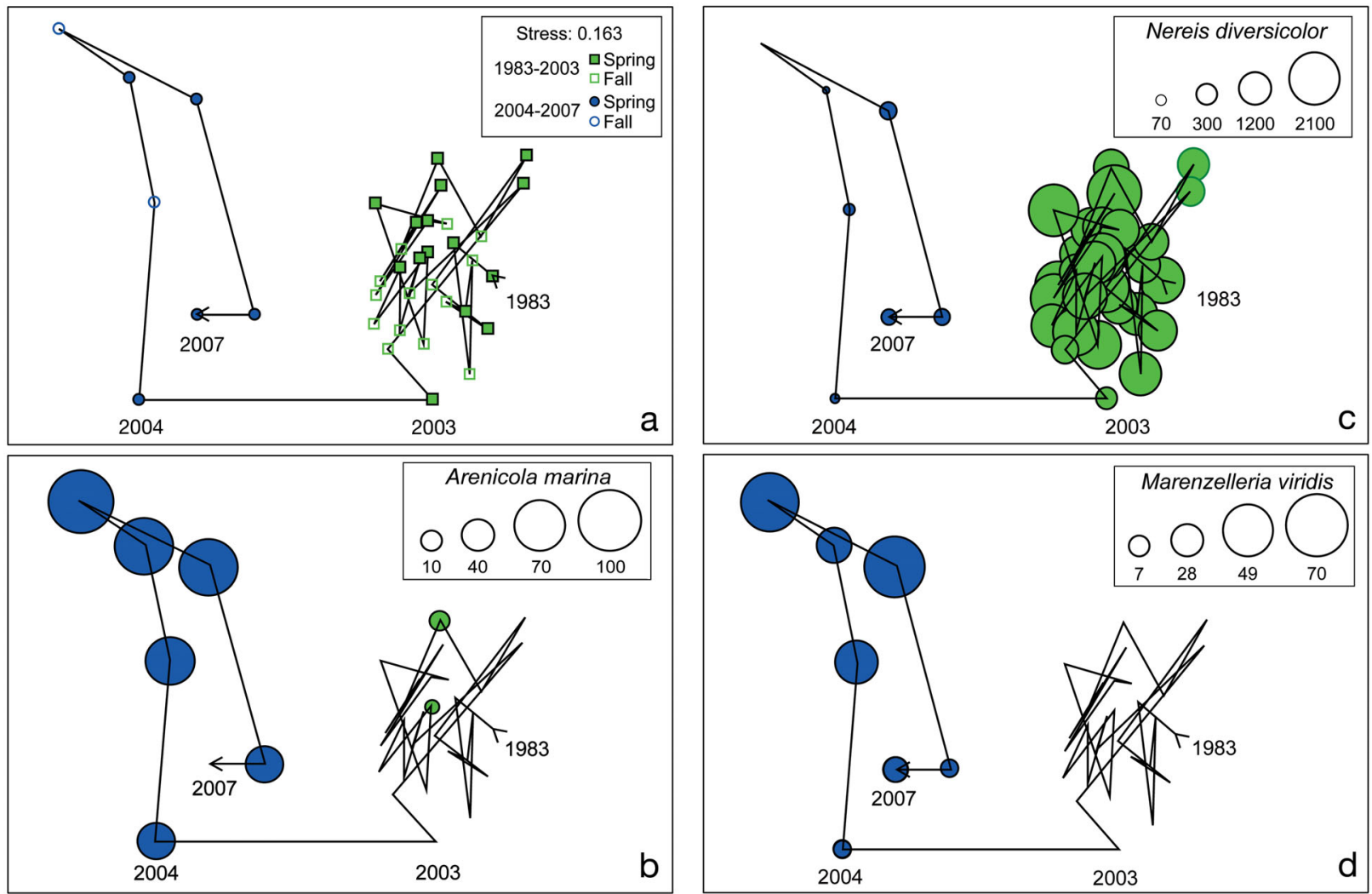

Fig. 5. Marenzelleria viridis, Arenicola marina and Nereis diversicolor. COM-temporal survey. (a) MDS ordination of temporal variations of the benthic community before (green squares) and after (blue circles) $M$. viridis introduction. The line connects communities that are consecutive in time. $(b, c, d)$ Same MDS with superimposed circles representing the average abundance (ind. $\mathrm{m}^{-2}, \mathrm{n}=10$ ) of $A$. marina, $N$. diversicolor or $M$. viridis
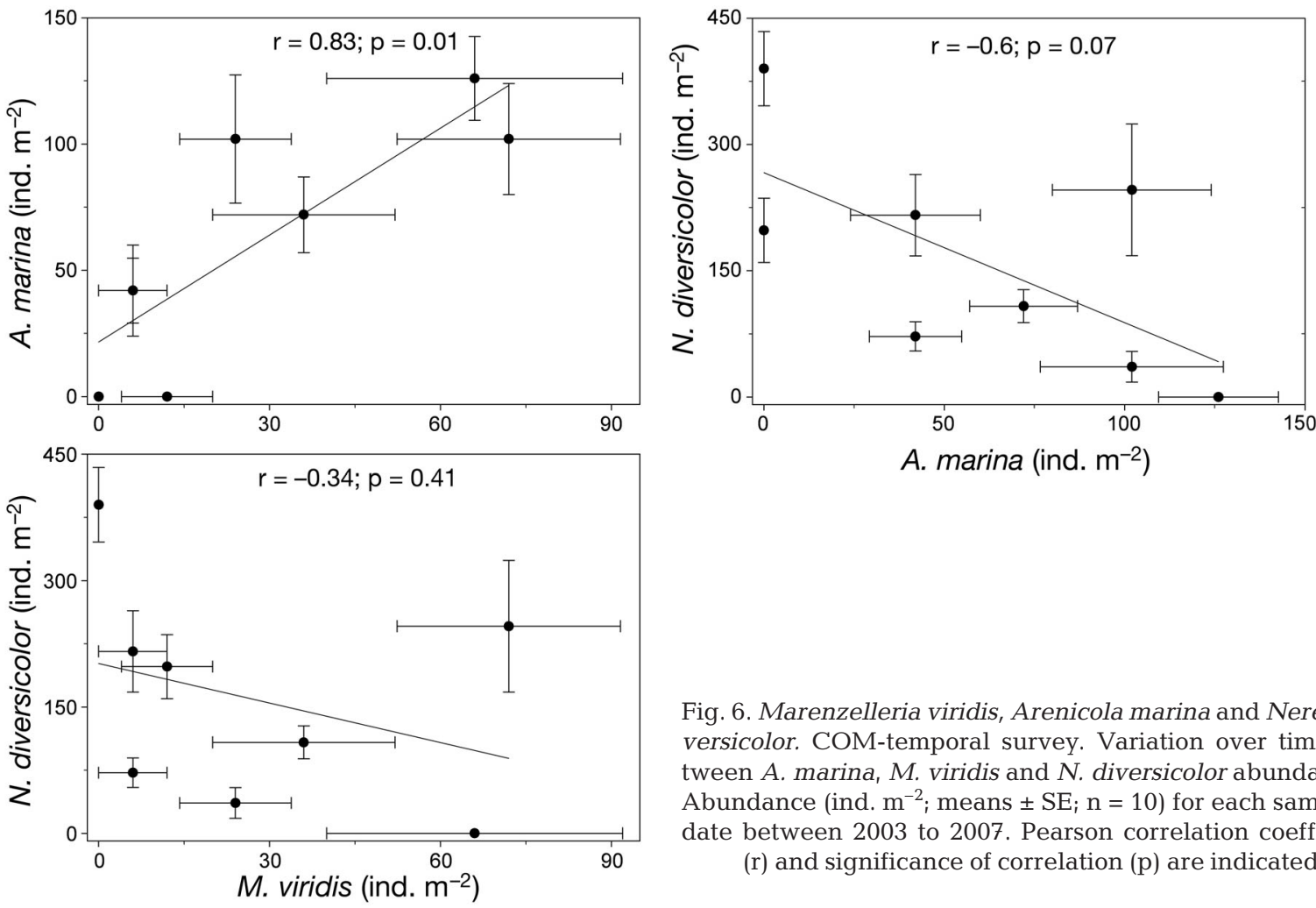

A. marina (ind. $\mathrm{m}^{-2}$ )

Fig. 6. Marenzelleria viridis, Arenicola marina and Nereis diversicolor. COM-temporal survey. Variation over time between A. marina, $M$. viridis and $N$. diversicolor abundances. Abundance (ind. $\mathrm{m}^{-2}$; means $\pm \mathrm{SE}_{;} \mathrm{n}=10$ ) for each sampling date between 2003 to 2007. Pearson correlation coefficient $(\mathrm{r})$ and significance of correlation $(\mathrm{p})$ are indicated 
Table 3. Marenzelleria viridis, Arenicola marina and Nereis diversicolor. MAN-spatial survey. Populations of the 3 species in Odense Fjord. Proportion (\%) of stations occupied by each species is reported as well as their average (maximum) population abundance (ind $\mathrm{m}^{-2}$ ) in the inner (28 stations) and outer (42) parts of the estuary

\begin{tabular}{|lcccccc|}
\hline \multirow{2}{*}{$\begin{array}{l}\text { Odense } \\
\text { Fjord }\end{array}$} & \multicolumn{2}{c}{ Marenzelleria viridis } & \multicolumn{2}{c}{ Arenicola marina } & \multicolumn{2}{c|}{ Nereis diversicolor } \\
Proportion & Abundance & Proportion & Abundance & Proportion & Abundance \\
\hline Inner & 37 & $80(1174)$ & 21 & $4(29)$ & 100 & $1148(3013)$ \\
Outer & 58 & $123(523)$ & 50 & $10(85)$ & 60 & $267(3169)$ \\
Whole & 50 & 107 & 38 & 7.6 & 76 & 607 \\
\hline
\end{tabular}

Besides the role of Nereis diversicolor, the BVSTEP procedure suggested that the crustacean Corophium spp., the bivalve Cerastoderma glaucum and the gastropods Littorina spp. and Hydrobiidae contributed to the overall community change by a decrease in abundance $\left(\rho_{\text {Spearman }}=0.95, \mathrm{p}<0.001\right.$; Table 2). Hydrobiidae and Littorina spp. were negatively correlated with $A$. marina $(\mathrm{r}=-0.87, \mathrm{p}=$ 0.04 , and $\mathrm{r}=-0.60, \mathrm{p}=0.01$, respectively) and $M$. viridis $(\mathrm{r}=-0.76, \mathrm{p}=0.003$, and $\mathrm{r}=-0.70, \mathrm{p}=0.05$, respectively).

\section{Polychaete spatial distribution (MAN-spatial)}

Marenzelleria viridis was present at $50 \%$ of all 70 surveyed stations (Table 3). It was most common in the outer part of the estuary where it was found at $58 \%$ of the 42 stations mainly in sandy and silty/ sandy sediment (Figs. $2 \& 7$ ). The presence of $M$. viridis was more restricted in the inner part of the estuary where it was found at $37 \%$ of the 28 stations, mainly in areas near the shipping channel. The average $M$. viridis density in Odense Fjord was $\sim 107$ with local maxima of up to $\sim 1200$ ind. $\mathrm{m}^{-2}$ (Table 3, Fig. 7).

Arenicola marina was observed at 27 out of the 70 stations. Similarly to Marenzelleria viridis, it was more commonly found in the outer part of the estuary (50\%) compared to stations located in the inner part of the estuary $(21 \%)$. The highest abundance of the large bodied lugworm was 85 ind. $\mathrm{m}^{-2}$ in the outer part of the estuary. The average abundance calculated from the 70 stations was $\sim 8$ ind. $\mathrm{m}^{-2}$ (Table 3 , Fig. 7).

Nereis diversicolor was found at $76 \%$ of all stations and was therefore the most widespread and abundant of the 3 polychaete species (Table 3). Only $N$. diversicolor was present at all 28 stations located in silt areas and at all stations in the inner part of Odense Fjord (Figs. $2 \& 7$ ). Its average density for the entire estuary was $\sim 600$ ind. $\mathrm{m}^{-2}$, but reached $>3000$ ind. $\mathrm{m}^{-2}$ at certain locations in particularly the inner part (Table 3, Fig. 7).

\section{DISCUSSION}

\section{Past and present distribution of Marenzelleria viridis}

Invasion. The population dynamics of Marenzelleria viridis in Odense Fjord as observed by the MVinvasion survey followed the 4 phase 'boom-bust' population development typical of many invaders
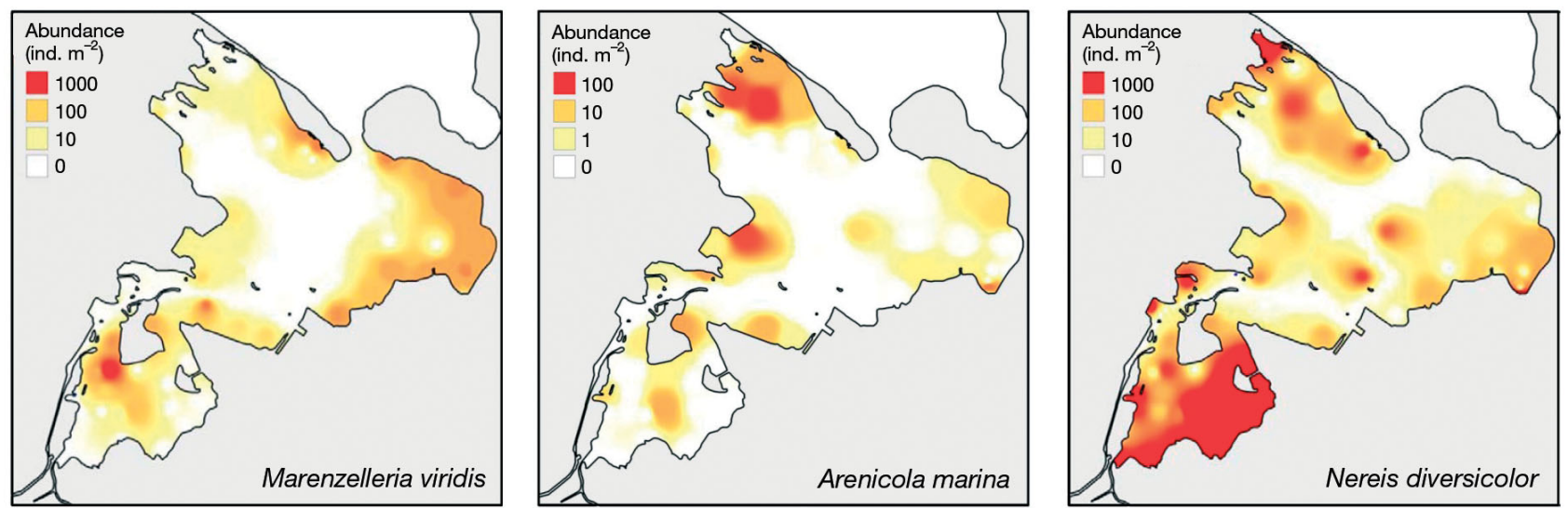

Fig. 7. Marenzelleria viridis, Arenicola marina and Nereis diversicolor. MAN-spatial survey. Populations of the 3 species in Odense Fjord for Years 2008 to 2010. Note: scales differ for each panel 
(Fig 4; Essink \& Dekker 2002, Reise et al. 2006). The first phase corresponds to the initial inoculation of the new species into the ecosystem. This occurred for $M$. viridis near the shipping channel in the inner part of Odense Fjord in 2002. Its pelagic larvae may have been introduced through the release of ballast water from ships or brought by the subsurface inflow of high saline seawater from the connecting sea (Blank et al. 2004, Josefson \& Hansen 2004). The second phase is a lag period where the newly established species after a successful introduction maintains a low but stable population for some time (Essink \& Dekker 2002, Reise et al. 2006). The duration of this phase is variable, but ecosystems with low species richness and high anthropogenic pressure tend to have shorter lag-phases because of their higher invasibility (Reise et al. 2006, Zaiko et al. 2011). The lagphase observed for $M$. viridis in the species-poor and eutrophic Odense Fjord was 1 to $2 \mathrm{yr}$ and is among the shortest reported in the literature for Marenzelleria spp. (Essink \& Dekker 2002). The third phase is typically expressed by rapid population growth (Essink \& Dekker 2002, Reise et al. 2006). This phase was obvious in Odense Fjord as a 10-fold increase of $M$. viridis abundance from 2003 to 2004. Such development has been reported elsewhere for both $M$. viridis (Essink \& Dekker 2002) and M. neglecta (Zettler et al. 2002) and has been attributed to the availability of an empty niche or unutilised food resources (Essink \& Dekker 2002, Reise et al. 2006). In the 4th phase of introduction, the population levels off to lower intermediate values (Essink \& Dekker 2002, Reise et al. 2006). The reasons of such decline remain hypothetical (Reise et al. 2006), but it could be attributed to decline of genetic population quality (consanguinity) or increased predation from birds and fish (Essink \& Kleef 1993, Essink \& Dekker 2002). Thus, at the end of the MV-invasion survey in 2007, the estimated average abundance of $M$. viridis in Odense Fjord was reduced to $\sim 50 \%$ of that in 2004 . The population dynamics of $M$. viridis suggests that the invasion in Odense Fjord lasted $5 \mathrm{yr}$ and was at its final stage in 2007. According to the 'boom-bust' population dynamic (Essink \& Dekker 2002), it is likely that densities measured in this estuary will remain in this range and will not reach levels observed in the Baltic (>9000 ind. $\mathrm{m}^{-2}$; Norkko et al. 2012). This is supported by the current average abundance of $M$. viridis measured in the estuary wide survey (MANspatial), but only future surveys of the area can provide more certainty on this matter.

Spatial distribution. The MV-invasion survey also indicates that Marenzelleria viridis spread from a single population near the shipping channel in the inner part to the entire $60 \mathrm{~km}^{2}$ estuary within $2 \mathrm{yr}$ (Fig. 3). A single introduction was probably sufficient for $M$. viridis to expand its geographical range. Compared to native polychaetes, it has the ability to spread rapidly due to a high reproductive capacity (up to 40000 eggs female ${ }^{-1}$ ) and larvae with a 1 to 3 mo pelagic stage (Essink \& Dekker 2002). Once introduced at 1 location, $M$. viridis generally maintained its presence throughout the duration of the MV-invasion survey. The small sample size used in this survey $\left(1 / 78 \mathrm{~m}^{2}\right)$ may have caused the minor temporal fluctuations in the grid occupation (50 to $75 \%$ ) by occasionally overlooking its presence at stations with low abundance.

The current distribution of Marenzelleria viridis obtained from the estuary-wide survey (MAN-spatial) confirms the generally successful establishment of this polychaete over the entire estuary. Both the historical (MV-invasion) and current spatial (MANspatial) distribution of $M$. viridis in Odense Fjord could arise from the limits of its environmental tolerance. It was not found at $2 / 3$ of the stations in the inner part of the estuary where the low winter salinity $(<5 \mathrm{psu})$ probably was beyond its physiological range (George 1966, Bochert 1997, Blank et al. 2004). The distribution of $M$. viridis in the outer estuary could be regulated by sediment conditions as salinity in this area remains $>15$ psu at all seasons. Its absence in impermeable silty sediments (Figs. 2, 3 \& 7) was probably a consequence of its specific burrowing lifestyle. It can probably only sustain adequate ventilation of the deep J- or I- shaped burrows and thus provide sufficient oxygen supply in permeable sandy sediments (Quintana et al. 2011).

\section{Effects of Marenzelleria viridis on the infauna community}

Perspectives for Nereis diversicolor. The MVinvasion survey revealed that the introduction of Marenzelleria viridis was synchronous with a $60 \%$ decrease in abundance of $N$. diversicolor in Odense Fjord. Nevertheless, $N$. diversicolor remains the prevailing polychaete species in this estuary (Fig. 4, Table 3). It is possible that $M$. viridis limited the abundance of $N$. diversicolor through competition for food and space (Kristensen 1988, Essink 1999) or reducing the recruitment and survival of juveniles by ventilation-driven upward percolation of sulphide rich water from burrows (Woodin et al. 1998, Kotta et al. 2001, Quintana et al. 2011). Alternatively, the 
overall abundance of $N$. diversicolor in Odense Fjord may have declined following recurrent hypoxic events in the early 2000s as in other Danish estuaries (Greve et al. 2005, Conley et al. 2007), creating an empty niche for the opportunistic (Essink \& Dekker 2002) and anoxia tolerant (Hahlbeck et al. 2000) $M$. viridis. Once established, $M$. viridis may have prevented the return of $N$. diversicolor to previous population levels observed at locations that were never colonised by $M$. viridis. Nevertheless, $N$. diversicolor is not likely to disappear completely from Odense Fjord as a consequence of the $M$. viridis invasion. Instead, it may coexist in low abundances with $M$. viridis or retreat to refuges where $M$. viridis cannot survive, e.g. low saline areas with silty sediment. It will be interesting to follow whether the currently established Nereis and Marenzelleria zones in Odense fjord are stable over time.

Relations with other infauna. The profound decline in the abundance of Nereis diversicolor after 2001 was not only correlated with the occurrence of Marenzelleria viridis, but also related to a concurrent expansion of the lugworm Arenicola marina. Antagonism between $A$. marina and $N$. diversicolor has often been reported and is primarily attributed to the continuous sediment mixing and thus physical disturbance induced by A. marina (Flach 1992, Zipperle \& Reise 2005, Volkenborn \& Reise 2006). However, the low population of $N$. diversicolor maintained after the subsequent disappearance of $A$. marina suggests that $M$. viridis may prevent the return of $N$. diversicolor (Fig. 5) as discussed above. The lack of correlation between $M$. viridis and $N$. diversicolor may be masked by the strong effect of $A$. marina that acted in concert with the negative influence of $M$. viridis.

Introduction of Marenzelleria viridis was according to the COM-temporal survey negatively correlated with the gastropods, Littorina spp. and Hydrobiidae. The interactions involved in these relations are unknown, but the mechanisms mentioned for its interaction with $N$. diversicolor may apply for the other species too. However, reworking activities of $A$. marina are also suggested to affect species like Cerastoderma glaucum, Corophium spp., Littorina spp. (Flach 1992) and have certainly contributed to the decline observed for these species in the COMtemporal survey.

The strong positive correlation between Arenicola marina and Marenzelleria viridis observed in the COM-temporal survey indicates that they may facilitate each other. This was unexpected and is to our knowledge the first observation of such a relation between these 2 species. However, $M$. viridis may mobilize nutrients from the sediment and stimulate microphytobenthic primary production and thereby increase food availability for A. marina (Riisgård \& Banta 1998, Kotta et al. 2001, Kristensen et al. 2011). The relation also suggests that $M$. viridis is able to survive and thrive well under the disturbance regime of A. marina, while several other infaunal species are severely hampered (Flach 1992, Riisgård \& Banta 1998). It is possible that $M$. viridis is capable of forming burrows deeper than those of $A$. marina thereby avoiding the strong surface disturbance. Conversely, A. marina may facilitate $M$. viridis by excluding potentially competitive species, including $N$. diversicolor, and thereby maintaining an 'empty' niche for M. viridis introduction (Flach 1992, Essink \& Dekker 2002).

It is important to note that recent massive disappearance of the seagrass Zostera marina in the outer part of the estuary may have created more suitable sites for Arenicola marina (Valdemarsen et al. 2011). There, the positive relationship between the Marenzelleria viridis and $A$. marina may therefore have facilitated the introduction of $M$. viridis and strengthened the competitive pressure on $N$. diversicolor.

\section{Ecological implications}

The polychaete Marenzelleria viridis is undoubtedly a new and persistent species in Odense Fjord. Irrespective of the consequences for the native benthic community, the ecological implications of such invasion must be assessed thoroughly. However, information from other studies on the consequences of Marenzelleria invasions must be evaluated carefully due to confusion in discriminating between Marenzelleria sibling species (Blank et al. 2008). Recent evidence indicates that the ecological function of $M$. neglecta from low saline eastern Baltic Sea areas is markedly different from that of $M$. viridis from high saline western Baltic Sea and North Sea areas (Norkko et al. 2012), probably owing to their different life traits, e.g. burrowing depth, sediment preference and bio-irrigation (Renz et al. unpubl. data). Unfortunately, only a few recent studies are available for understanding the ecological effects of M. viridis in Danish coastal waters (Quintana et al. 2007, 2011, Kristensen et al. 2011).

The present study indicates that the invasive Marenzelleria viridis in Odense Fjord is competitively superior to the native Nereis diversicolor. This effect is more apparent when abiotic (e.g. anoxia) or biotic (e.g. Arenicola marina) disturbance events 
favour $M$. viridis compared to $N$. diversicolor. There are possible positive aspects related to the introduction of $M$. viridis in Odense Fjord, such as increased species richness and an additional food source for fish (Essink \& Kleef 1993, Rosa et al. 2008), with implications on resilience and stability of the system (Schlaepfer et al. 2011). However, population changes in important key species such as $N$. diversicolor and $A$. marina as a consequence of the $M$. viridis invasion may have significant ecological consequences given that bioturbation (ventilation and particle reworking) by these 3 polychaete species is very different, both in scale and intensity (Kristensen et al. 2012). This may significantly affect the biological (Valdemarsen et al. 2011, Delefosse \& Kristensen 2012), chemical (Banta et al. 1999, Kristensen et al. 2011) and physical (Volkenborn et al. 2007) environment in Odense Fjord.

Acknowledgements. We thank E. Glob from the Nature Management and Water Environmental Division of the Fyn County and C. B. Pedersen from the Ministry of Environment of Odense for providing access to their historical database. We are also grateful for assistance in the field by M. D. Kristiansen, T. Lange and T. Reuss Schmidt, and in the laboratory by D. Crunelle, P. Gandolfo Castiñeira, B. Sweeten Elemans, D. Sørensen and K. Wendelboe. We thank K. Povidisa, M. Holmer, K. Reise, J. L. S. Hansen and 3 anonymous reviewers for improving an earlier version of the manuscript and M. Anderson for her suggestions on some of the unpublished statistical analysis. This study was supported by the Danish Strategic Science Foundation (contract no. 09063190) and the Danish Council for Independent Research (contract no. 272-08-0577 and no. 09-071369).

\section{LITERATURE CITED}

Banta GT, Holmer M, Jensen MH, Kristensen E (1999) Effects of two polychaete worms, Nereis diversicolor and Arenicola marina, on aerobic and anaerobic decomposition in a sandy marine sediment. Aquat Microb Ecol 19: 189-204

Blank M, Bastrop R, Rohner M, Jurss K (2004) Effect of salinity on spatial distribution and cell volume regulation in two sibling species of Marenzelleria (Polychaeta: Spionidae). Mar Ecol Prog Ser 271:193-205

> Blank M, Laine AO, Juerss K, Bastrop R (2008) Molecular identification key based on PCR/RFLP for three polychaete sibling species of the genus Marenzelleria, and the species' current distribution in the Baltic Sea. Helgol Mar Res 62:129-141

Bochert R (1997) Marenzelleria viridis (Polychaeta: Spionidae): a review of its reproduction. Aquat Ecol 31: 163-175

> Cederwall H, Jermakovs V, Lagzdins G (1999) Long-term changes in the soft-bottom macrofauna of the Gulf of Riga. ICES J Mar Sci 56:41-48

Christoffersen K (2010) Distribution of the invasive polychaete Marenzelleria spp. in Danish waters: relation- ships to the benthic community and the environment. MSc thesis, Roskilde University (in Danish)

Clarke KR (1993) Nonparametric multivariate analyses of changes in community structure. Aust J Ecol 18:117-143

Clarke KR, Gorley RN (2006) PRIMER V6: user manual/tutorial. Primer-e, Plymouth

Clarke KR, Warwick RM (1998) Quantifying structural redundancy in ecological communities. Oecologia 113: 278-289

Clarke KR, Chapman MG, Somerfield PJ, Needham HR (2006a) Dispersion-based weighting of species counts in assemblage analyses. Mar Ecol Prog Ser 320:11-27

Clarke KR, Somerfield PJ, Chapman MG (2006b) On resemblance measures for ecological studies, including taxonomic dissimilarities and a zero-adjusted Bray-Curtis coefficient for denuded assemblages. J Exp Mar Biol Ecol 330:55-80

Conley DJ, Kass H, Møhlenberg F, Rasmussen B, Windolf J (2000) Characteristics of Danish estuaries. Estuaries 23: 820-837

Conley DJ, Markager S, Andersen J, Ellermann T, Svendsen LM (2002) Coastal eutrophication and the Danish national aquatic monitoring and assessment program. Estuaries 25:848-861

Conley DJ, Carstensen J, Aertebjerg G, Christensen PB, Dalsgaard T, Hansen JLS, Josefson AB (2007) Long-term changes and impacts of hypoxia in Danish coastal waters. Ecol Appl 17:S165-S184

Delefosse M, Kristensen E (2012) Burial of Zostera marina seeds in sediment inhabited by three polychaetes: laboratory and field studies. J Sea Res 71:41-49

> Essink K (1999) Dispersal and development of Marenzelleria spp. (Polychaeta, Spionidae) populations in NW Europe and the Netherlands. Helgol Meersunters 52:367-372

> Essink K, Dekker R (2002) General patterns in invasion ecology tested in the Dutch Wadden Sea: the case of a brackish-marine polychaetous worm. Biol Invasions 4:359-368

$>$ Essink K, Kleef H (1993) Distribution and life cycle of the North American spionid polychaete Marenzelleria viridis (Verrill, 1873) in the Ems estuary. Aquat Ecol 27:237-246

- Flach EC (1992) Disturbance of benthic infauna by sediment reworking activities of the lugworm Arenicola marina. Neth J Sea Res 30:81-89

George JD (1966) Reproduction and early development of spionid polychaete Scolecolepides viridis (Verrill). Biol Bull 130:76-93

> Gollasch S (2006) Overview on introduced aquatic species in European navigational and adjacent waters. Helgol Mar Res 60:84-89

> Greve TM, Krause-Jensen D, Rasmussen MB, Christensen PB (2005) Means of rapid eelgrass (Zostera marina L.) recolonisation in former dieback areas. Aquat Bot 82: 143-156

Hahlbeck E, Arndt C, Schiedek D (2000) Sulphide detoxification in Hediste diversicolor and Marenzelleria viridis, two dominant polychaete worms within the shallow coastal waters of the southern Baltic Sea. Comp Biochem Physiol B 125:457-471

Jørgensen B, Demétrio CGB, Kristensen E, Banta GT, Petersen HC, Delefosse M (2011) Bias-corrected Pearson estimating functions for Taylor's power law applied to benthic macrofauna data. Stat Probab Lett 81:749-758

$>$ Josefson AB, Hansen JLS (2004) Species richness of benthic macrofauna in Danish estuaries and coastal areas. Glob Ecol Biogeogr 13:273-288 
Kotta J, Orav H, Sandberg-Kilpi E (2001) Ecological consequence of the introduction of the polychaete Marenzelleria cf. viridis into a shallow-water biotope of the northern Baltic Sea. J Sea Res 46:273-280

Kristensen E (1988) Factors influencing the distribution of nereid polychaetes in Danish coastal waters. Ophelia 29: 127-140

Kristensen E, Hansen T, Delefosse M, Banta GT, Quintana $\mathrm{CO}$ (2011) Contrasting effects of the polychaetes Marenzelleria viridis and Nereis diversicolor on benthic metabolism and solute transport in sandy coastal sediment. Mar Ecol Prog Ser 425:125-139

Kristensen E, Penha-Lopes G, Delefosse M, Valdemarsen T, Quintana CO, Banta GT (2012) What is bioturbation? Need for a precise definition for fauna in aquatic science. Mar Ecol Prog Ser 446:285-302

Leppäkoski E, Olenin S (2000) Non-native species and rates of spread: lessons from the brackish Baltic Sea. Biol Invasions 2:151-163

Mitas L, Mitasova H (1999) Spatial interpolation. In: Longley P, Goodchild MF, Maguire DJ, Rhind DW (eds) Geographical information systems: principles, techniques, management and applications. GeoInformation International, Wiley, New York, NY, p 481-492

$>$ Norkko J, Reed DC, Timmermann K, Norkko A and others (2012) A welcome can of worms? Hypoxia mitigation by an invasive species. Glob Change Biol 18:422-434

> Quintana CO, Tang M, Kristensen E (2007) Simultaneous study of particle reworking, irrigation transport and reaction rates in sediment bioturbated by the polychaetes Heteromastus and Marenzelleria. J Exp Mar Biol Ecol 352:392-406

Quintana CO, Hansen T, Delefosse M, Banta G, Kristensen E (2011) Burrow ventilation and associated porewater irrigation by the polychaete Marenzelleria viridis. J Exp Mar Biol Ecol 397:179-187

Reise K, Simon M, Herre E (2001) Density dependent recruitment after winter disturbance on tidal flats by the lugworm Arenicola marina. Helgol Mar Res 55:161-165

Reise K, Olenin S, Thieltges D (2006) Are aliens threatening European aquatic coastal ecosystems? Helgol Mar Res 60:77-83

Ricciardi A, Rasmussen JB (1998) Predicting the identity and impact of future biological invaders: a priority for aquatic resource management. Can J Fish Aquat Sci 55: 1759-1765

Riisgård HU, Banta GT (1998) Irrigation and deposit feeding by the lugworm Arenicola marina, characteristics and secondary effects on the environment. A review of current knowledge. Vie Milieu 48:243-257

$>$ Riisgård HU, Seerup DF, Jensen MH, Glob E, Larsen PS

Editorial responsibility: Richard Osman,

Edgewater, Maryland, USA
(2004) Grazing impact of filter-feeding zoobenthos in a Danish fjord. J Exp Mar Biol Ecol 307:261-271

Riisgård HU, Jensen MH, Rask N (2008) Odense Fjord and Kerteminde Fjord/Kertinge Nor. In: Schiewer U (ed) Ecology of Baltic coastal waters. Ecological Studies 197. Springer, Berlin, p 361-394

> Rosa S, Granadeiro JP, Vinagre C, Franca S, Cabral HN, Palmeirim JM (2008) Impact of predation on the polychaete Hediste diversicolor in estuarine intertidal flats. Estuar Coast Shelf Sci 78:655-664

Schlaepfer MA, Sax DF, Olden JD (2011) The potential conservation value of non-native species. Conserv Biol 25: 428-437

Somerfield PJ, Clarke KR (1995) Taxonomic levels, in marine community studies, revisited. Mar Ecol Prog Ser 127:113-119

Thomsen MS, Wernberg T, Silliman BR, Josefson AB (2009) Broad-scale patterns of abundance of non-indigenous soft-bottom invertebrates in Denmark. Helgol Mar Res 63:159-167

Valdemarsen T, Wendelboe K, Egelund JT, Kristensen E, Flindt MR (2011) Burial of seeds and seedlings by the lugworm Arenicola marina hampers eelgrass (Zostera marina) recovery. J Exp Mar Biol Ecol 410:45-62

> Volkenborn N, Reise K (2006) Lugworm exclusion experiment: responses by deposit feeding worms to biogenic habitat transformations. J Exp Mar Biol Ecol 330:169-179

> Volkenborn N, Hedtkamp SIC, van Beusekom JEE, Reise K (2007) Effects of bioturbation and bioirrigation by lugworms (Arenicola marina) on physical and chemical sediment properties and implications for intertidal habitat succession. Estuar Coast Shelf Sci 74:331-343

> Woodin SA, Marinelli RL, Lindsay SM (1998) Process-specific cues for recruitment in sedimentary environments: geochemical signals? J Mar Res 56:535-558

Zaiko A, Lehtiniemi M, Narscius A, Olenin S (2011) Assessment of bioinvasion impacts on a regional scale: a comparative approach. Biol Invasions 13:1739-1765

Zettler ML, Daunys D, Kotta J, Bick A (2002) History and success of an invasion into the Baltic Sea: the polychaete Marenzelleria cf. viridis, development and strategies. In: Leppakoski E, Gollasch S, Olenin S (eds) Invasive aquatic species of Europe: distribution, impacts and management. Kluwer Academic, Dordrecht

> Zipperle A, Reise K (2005) Freshwater springs on intertidal sand flats cause a switch in dominance among polychaete worms. J Sea Res 54:143-150

Zmudzinski L (1996) The effect of the introduction of the American species Marenzelleria viridis (Polychaeta: Spionidae) on the benthic ecosystem of Vistula Lagoon. PSZN I: Mar Ecol 17:221-226

Submitted: March 9, 2012; Accepted: May 14, 2012 Proofs received from author(s): July 30, 2012 